\section{Chinese exchanges easier}

China has begun trying to achieve the four modernisations-agriculture, industry and defence with science and technology as the 'key'-in accordance with the policy laid out in Chairman Hua's Political Report to the Party Congress last August. The plan for agricultural modernisation over the next three years was revealed on 26 January in a report to the third national conference on agricultural mechanisation.

In spite of these moves towards achieving China's new goal, however, discussions are still taking place on the future of many aspects of national life. In education, for example, it has been reported that the advice of a top leader has been sought on a question not resolved at ministry level. It is unlikely, however, that this concerned the egalitarian drives to set up an 'open university' via the national television network and to make universal by 1985 middle-school education in the cities and junior middleschool education in rural areas. The overall picture, however, is that progress in education is regaining momentum; an All-National Conference on Education will be held after the one on science in

China is also implementing plans to increase international academic exchange. The situation report delivered last December by Fang-Yi, VicePresident of Academia Sinica, reiterated that China is striving to learn advanced science and technology from foreign countries whilst keeping to the principle of self-reliance and independence. Already, some scientists of Chinese origin have been led to believe that they will be invited to China at some stage in the near future for short term teaching and/or research. And there is also no question that China will employ many foreign experts.

An ordinary tour of China can be simply arranged. Last month's issue of China Reconstructs published a guide for prospective applicants, either single or in a group. A technical visit, such as a visiting professorship, will probably have to go through personal connections or organisations such as the revitalised Chinese Scientific and Technical Association, whose acting chairman is Chou Pei-yuan of Peking University. Chou (a physicist) may in fact be regarded as in charge of academic matters in research and education, and Fang $\mathrm{Yi}$ as in charge of political and general concerns.

The Japanese, however, have gone some way to taking the initiative in fostering exchange with China: an Association for Japanese-Chinese Scientific Exchange was founded in Tokyo last December. The French also recently signed a Science and Technology Agreement with China covering, amongst other cooperative schemes, the exchange of scientists. Incidentally, M Barre's state visit to China also resulted in another development: Hua's acceptance of an invitation from Giscard d'Estaing to his country. That will make France, an old friend of China's, the second country in the world that a Chinese Communist Party Chairman has ever visited.

T. B. Tang
Most countries have their own units of length, weight and volume, and several systems for measuring temperature have been used in different parts of the world. These different units present difficulties to travellers, and to the communication of scientific results between nations. Many years ago, on a walking holiday in Sweden, I set off for a village which a signpost said was three miles away. After striding along at a reasonable pace for nearly two hours I saw a second sign saying that I still had to cover two miles. Thus I learned that one Swedish mile was equal to six English miles.

On another occasion at a seaside resort in Denmark I saw a notice which said that the temperature of the sea was 16 degrees. I hestitated to bathe, for this seemed a little chilly, but when I overcame my reluctance I found the water warmer than expected. The temperature had been recorded on the Réaumur scale, and corresponded to 20 degrees Celsius, or 68 degrees Fahrenheit.

It seems sensible to come to some agreement so that the same units are used internationally. For a long time scientists in Britain and many other countries have followed two systems, metric in the laboratory, and 'traditional' outside. We are now trying to change and are using the metric system everywhere. Unfortunately, this rational change makes life less interesting. It was always pleasant to find maunds and seers in India, and quite easy to make the necessary conversions. I was glad to find recently in Mauritius that land is still measured by the arpent ( 1.043 acre). British farmers are urged to go metric, but they still think, and usually talk, of yields in hundredweights per acre, though the bushel has largely disappeared.

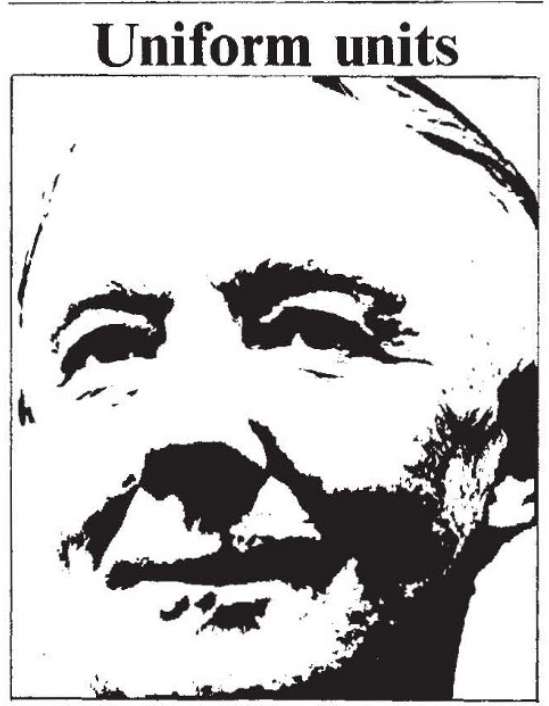

KENNETH MELLANBY

Those of us brought up in the laboratory on what are now old-fashioned metric units find the SI system difficult to use. I really cannot understand why I must stop talking about cubic centimetres, for this is a sensible unit and is easily understood. The change to millilitres seems to be unjustified.

Even more important than using the same units (for these can easily be con- verted) is to have the same meaning for words. In Britain and most of Europe the billion has always been $10^{12}$. North Americans, thought by Europeans to be prone to exaggeration, give the word the value of only $10^{9}$. I despair of converting Americans back to the correct use of the term, and see no reason to follow their bad example. I therefore believe that the term has become so ambiguous that it should no longer be used. As an editor I ban it from my journal. Recently I have been shocked to see that Nature has allowed the word, with its American use, to appear in its columns. I hope that all my readers will support my campaign for the total abolition of the billion in any form.

In Britain we have even decimalised our currency, and lost our useful shillings and pence. One more exotic coin, the guinea, has not yet disappeared cntirely. It is still used for selling expensive race horses and to pay for private medical treatment. The guinea was originally the same as the pound sterling, and was made up of twenty shillings. However, from 1717 gold sovereigns (pounds) made of Guinea gold from West Africa were found to be so pure that they were officially valued at twenty-one shillings. I recently received a bill for dental treatment for fifty guineas; this was converted by a young clerk into $£ 55$. She apparently thought that with decimalisation the guinea was now $£ 1.10$ instead of the original $£ 1.05$. No wonder people think that decimalisation has helped to increase the rate of inflation. 